\title{
THE HUNTER OF MAN
}

Maj E M Malone*

The origins of sniping - the ability to kill one's enemy at a range far exceeding that of ordinary military rifles - may be traced at least as far back as 1755 , in which year the British Government, licking their wounds after an inglorious defeat on the banks of the Ohio River by a combined French and Red Indian force, raised from among the American settlers a unique corps of trained marksmen, whose arms, dress and mobility approximated those of their enemies. This corps d'elite, whose birthday is given as Christmas Day 1755, was orignally named the 2nd Regiment, the title being subsequently altered to the 60th 'Royal Americans'.

The 60th, snipers and sharpshooters from the beginning, together with the famous 95th Rifles, made their reputation during the Peninsular War in the opening years of the 19th century when, armed with the new Baker rifle, they made life difficult - and death easy - for Napoleon's unfortunate troops in Spain and Portugal. The standard infantry weapon of that time in the French and British armies, was the legendary 'Brown Bess' smoothbore flintlock (and its basically similar French counterpart), firing a ball of approximately $.750 "$ calibre, weighing about one ounce. Anyone unfortunate enough to find himself at the receiving end of the 'Brown Bess' was out of luck. Doubly out of luck, because the chances of being hit by a deliberately aimed shot from that long, ponderous and wildly inaccurate weapon at anything in excess of one hundred yards, were minimal. It was the unaimed shot - or one aimed at somebody else - that one had to worry about.

This, however, did not apply to the Baker rifle which, although also a singleshot flintstock, was shorter and handier than the 'Brown Bess' and, because of its rifled barrel, incomparably more accurate. In skilled hands, in fact, it could bring down a man at about 300 paces and, in the hands of a master, at 400 . By the standards of those days, that was fantastic shooting. It is by no means bad, even today.

The concern which the green-jacketed Riflemen and their shooting prowess aroused in the breasts of their French opponents was expressed by Marshall Soult ( $\mathrm{C}$-in-C of the French.
Army in Spain) in a letter to the French Minister of War in Paris, dated 1st September 1813. Soult informed the Minister that 'the loss of prominent and superior officers is so disproportionate to that of the rank and file' that he had gone to some pains to discover the cause of the high mortality rate among his senior officers.

'There is', he wrote, 'in the English Army, a Battalion of the 60th which is never concentrated, but has a Company attached to each Infantry Division. It is armed with a short rifle; the men are selected for their markmanship. In action they are expressly ordered to pick off officers, especially Field or General officers. Thus it has been observed that whenever a superior officer goes to the front during an action, either for the purpose of observation or to lead and encourage his men, he is usually hit. This mode of making war is very detrimental to us. I have seen battalions which have been reduced to two or three officers although less than one-sixth of their men has been disabled'. One of the Marshall's staff subsequently declared that 'Les Riflemen' killed all our officers between 25th July and 30th August 1813, viz approximately 500 officers and 8 Generals'.

This sort of thing was regarded by the French as somewhat ungentlemanly 'for the reason that their fire was deliberately aimed, a practice considered unfair'. It is to be noted, however, that the lack of 'gentility' involved was apparent only to the side at the receiving end. The student of military history will recall, with wry amusement, that similar criticism was levelled at the Boer forces by the British in 1881, the latter (as is the almost invariable custom of Armies) having forgotten their own hard-learned lesson. The Boers, it was claimed, were 'ungentlemanly' for lying down and shooting from behind cover, 'instead of standing up like men'. It is a criticism which would, presumably, have brought a blush to the cheeks of the gallant 60th and 95th in 1810, who were adept at sniping from behind rocks and any other available cover. One can only assume that they reclined in a more gentlemanly fashion.

However, let us revert to the main subject, the gentle (and deadly) art of the sniper. 
During the American Civil War of the 1860's, of which the last survivor died only some thirty years ago, the sniper again came to the fore, particularly among the Northern forces which, being wealthier, were better equipped than their Southern adversaries. Although blackpowder weapons were still, of course, used by both sides, the Northern Armies were in a position to provide themselves with a corps of snipers equipped with telescopic sights with which heavy casualties were inflicted at ranges exceeding 600 yards on key Southern personnel. At least one General died at the hands of a sniper at 700 yards and hits at that range were by no means exceptional. The percussion-lock rifle with its faster ignition - then generally in use - was naturally a considerable help to the precision, long range shot.

The British, in their turn, found themselves at the receiving end of snipers' rifles during the last quarter of the century on the North-West Frontier of India where the Pathan marksmen, according to Kipling,

'Being blessed with perfect sight,

Picked off our messmates left and right

One of the last of the British 'messmates' so to be 'picked off' still survives, now an ex-officer of the late and lamented Rhodesian Army. Some two years ago - then a very old man - he showed me the white scar of a Martini-Henry lead bullet along his ribs, fired by a Pathan sniper in the Khyber pass in the 1920's. He claims to have seen the puff of smoke, from the rifle that bagged him, about 450 yards away on the hillside. The effect, he said, 'was like being kicked by an Army mule'. The Pathans, of course, had never heard of such luxuries as telescopic sights, but appear to have done very well without them. Their 'perfect sight' nou doubt helped. Like their contemporaries, the 19th century Boers, they were born with a love of rifles, and used them like the experts they were. The Pathans, in their highland fastnesses, still do so, (as also, it seems, do their valiant Afghan kinsmen). May Providence forfend that we ourselves should ever forget the art. It is a deficiency for which we should pay dearly in the years to come.

During the Anglo-Boer War of 1899-1902 our forces, for more than three years, held at bay the most powerful Empire the world has yet seen. We did so because we could outshoot their troops and out-general their generals - and because in the $7 \mathrm{~mm}$ Mauser rifle, even without benefit of telescopic sights, we had the advantage of a superbly accurate, flat-shooting weapon. Had this not been the case, the war would have ended for us in ignominy and disaster. Our ability to use the rifle as it should be used spared us from ignominious defeat and preserved our pride. It also paved the way for eventual political victory.

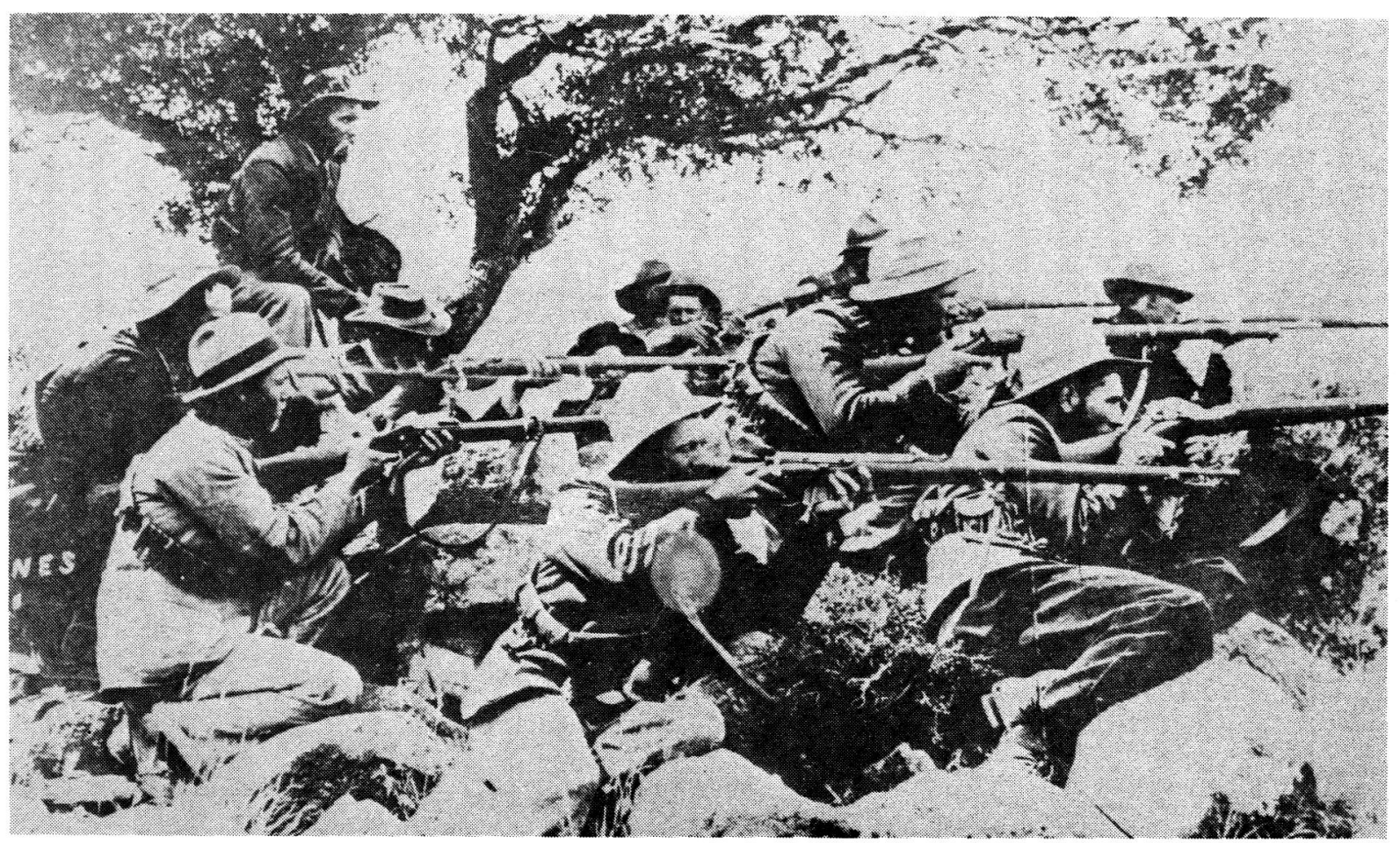

Boer Sharpshooters distinguished themselves as excellent shots during the Anglo-Boer War 
The Great War (to end all wars) of 1914-18 saw the resurgence of snipers on both sides, trench warfare providing ideal conditions for the expert rifleman, using a telescopic-sighted weapon from a fixed and hidden position at a known range. The casualties inflicted upon their opponents by snipers on both sides were (as is invariably the case) out of all proportion to their numbers. The effect upon enemy morale was even greater.

In 1914 the Germans were the first to introduce skilled sniping, and the Duke of Ratisbor's Jägers, recruited from German foresters and equipped with scope-sighted rifles, inflicted many casualties among British officers, NCO's and men before any steps were taken to stop the massacre. As a British officer subsequently wrote, "it should be borne in mind how great a menace were the skilled German snipers opposed to us. One of them might easily cause thirty or forty casualties. Later in the war we had, on our side, many a sniper who killed his fifty or even his hundred of the enemy. But in the early days of the war, the continual attrition caused by German snipers was very bad for our morale'.

For some time after the inception of German sniping it was thought that the heavy Allied casualties were caused not by aimed fire but by 'stray bullets'. It was only when some unusually percipient Staff Officer pointed out that these 'stray bullets' appeared to have a penchant for striking the unfortunate victim in the head or heart that the full significance of sniping belatedly dawned on authority. The British then recalled the lessons of the Napoleonic Wars, of South Africa and of the North-West Frontier of India and hurriedly established Sniper Schools. By 1917 the British and Canadian snipers in France had succeeded in dominating their German counterparts and, as a result, 'it was noticeable that men on our side again became human and walked upright, and their morale increased a thousand-fold'.

The Canadians, in particular, took to the sniping game like ducks to water, and their total tally by the end of the War was enormous. It is estimated that during 1916 British and Allied snipers accounted for the equivalent of three battalions of their enemy, many of them officers, observers, machine gunners, and other key personnel. One sniper claimed a bag of ten Bavarian Infantrymen in one evening from a hide on the Bapaume Road.
When the war ended in 1918, history repeated itself, and in 1939 a knowledgeable observer wrote of the British Army that 'the almost total lack of fundamental knowledge of firearms and shooting found in many Servicemen, from the private soldier to high-ranking officers, has to be experienced to be believed'.

A few devoted souls, however, kept the spirit of sniping alive and the outbreak of World War II saw almost every participating nation using some form of sniper rifle, incorporating the telescopic sight. Virtually all the sights used were of the 'hunting scope' type - strong, compact, securely mounted and fairly low powered. The United States, the greatest manufacturer of hunting rifles in the world, incredibly had no effective sniping equipment in its military forces at the commencement of the war. Once again, the lesson had to be learned the hard way. The Germans, however, had never forgotten.

The Germans, during World War II, were probably the most capable snipers. Courageous and well-trained, they were the outstanding marksmen of the Wehrmacht. Their skilful shooting inflicted tens of thousands of casualties throughout Europe, Russia and wherever the German Army fought. Their frightening effectiveness was most marked by mid-1943, when the German armies were no longer the splendid offensive forces of a few years earlier. Critically over-extended in men and resources, they became masters of static defence and strategic withdrawel, constantly exacting bloody tolls from the Allied forces with each stubborn backward step. The superbly trained German snipers, confident in their roles as military 'hunters', displayed effective shooting at anything moving or still up to 700 yards and above. They were armed with a well-designed assortment of weaponry and optics, night-sights, accurised $7.92 \mathrm{~mm}$ Karabiner $98 \mathrm{~K}$ bolt-action rifles and special match-grade ammunition. The selection standards for German snipers were exceptionally severe. The basic requirement was to be an excellent shot, but this asset had to be combined with moral and physical courage, hunting instincts and skills, selfcontrol, an advanced level of fieldcraft, and an ability to remain motionless for hours on end without losing concentration or nerve.

The German snipers' badge depicted a black eagle's head, bordered with oak leaves. They were issued in three classes, the $3 r d$ class for 20 confirmed kills, the 2 nd class (silver border) for 40 kills, and the 1st class (gold border) for 60 
kills. The standard task of the sniper was to seek out and kill enemy officers, NCO's, runners, mortar and machinegun crews, anti-tank gunners, exposed tank commanders and - in Russia - the ubiquitous Political Commissars.

These tasks they carried out with deadly efficiency. Their memory is indelibly imprinted upon the minds of many surviving World War II combat soldiers who personally experienced the spinechilling warning shout of 'SNIPER'! and heard the sickening crack and thump which heralded the death of a friend or comrade at their side.

War, alas, has throughout the centuries been one of the recurrent disasters of human history. If we are forced to wage it, however, it is as well to do so effectively and, in preparing to do so, remember the hard-learned lessons of the past. One of these lessons is the importance of the skilled sniper, especially to a small nation (such as ours) where limited manpower must be utilised to the maximum possible advantage. This implies good snipers, good training, good weapons and good equipment. Snipers are no less relevant to 'the savage wars of peace', where the Police and Army marksman, on the roof of a tactically-situated building, can render invaluable service in the control of riots, subversion and mob-violence. Northern Ireland is a case in point.
As regards training, experience has shown that it is far more difficult to hit a certain spot on a human figure, at any range, than it is to contact the same size spot on a target. The natural posture of man, such as lying down on a slope, results in a much 'trickier' target being presented than anything normally encountered on a rifle range. The obvious conclusion is that realistic sniping practice and experience (apart from the 'real thing') can only be gained by the use of lifesize and lifelike dummy targets at unknown distances and in a variety of positions.

Finally and above all, to anyone who really understands what sniping is all about, it is almost sacrilegious to talk of an automatic sniper rifle. It is equivalent to expecting Professor Chris Barnard to carry out a delicate heart operation with a kitchen knife! As Captain H.W. McBride, a renowned United States sniping expert, expressed it: 'To think that a sniper could or would ever do rapid fire through a telescopic sight or need to load with a clip shows nothing short of incredible ignorance'. The ideal for the sniper remains the heavy barrel bolt-action precision rifle, firing, with Match ammunition and firmly-mounted telescopic sight, the one true shot which counts for everything - the shot that kills. We forget this and the lessons of our own history, at our peril.

*Maj. E.M. Malone of Army Headquarters Pretoria, was awarded third prize for the above contribution to the Military Essay Competition of 1980 .

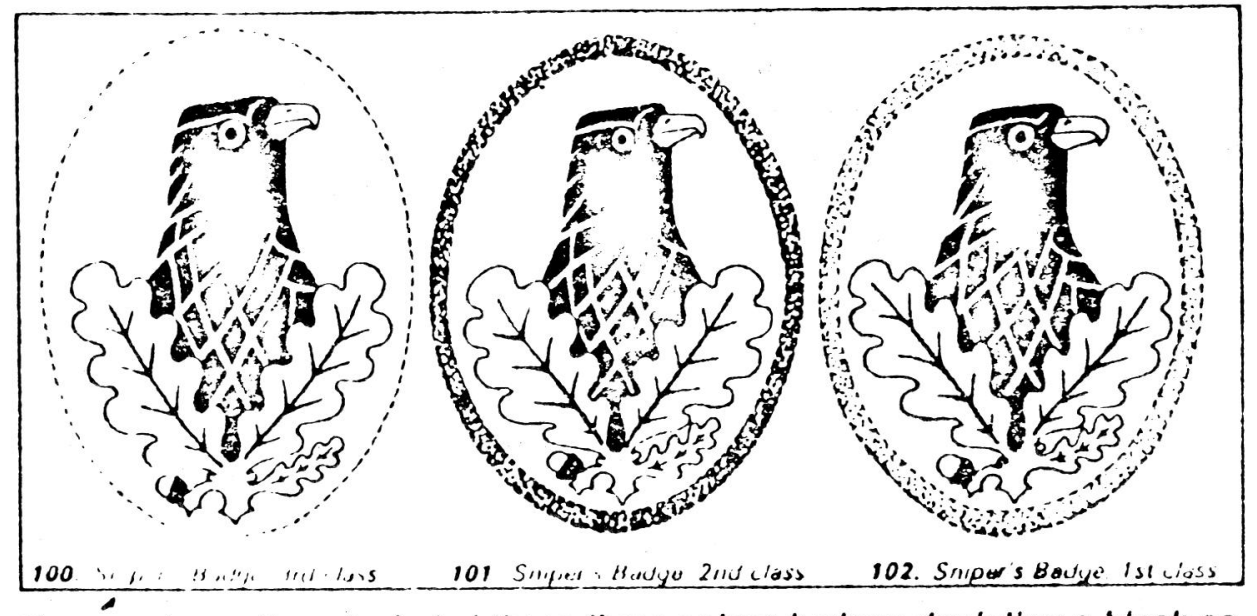

German decorallons included these threo snlper badges deplcting a black eagle's head alld oak loavos. From lell, ehird class for 20 conlirmod kills; second clas with silvoi border in kills. Iirst class with gold, 60 kills. 